\title{
Matching animal potential to climate and feed resource
}

\author{
E.R. Ørskov \\ Macaulay Land Use Research Institute \\ Craigiebuckler, Aberdeen, AB15 8QH, Scotland
}

\begin{abstract}
The ability of indigenous animals to adapt to climate and quality of feed resources and to fluctuating supply of nutrients is outlined. It is argued that the intensive animal production systems adapted in many industrialised countries has generally been based on selection for single traits e.g. milk, meat, wool etc. and largely under human control of the environment. This contrasts with the indigenous animals in less industrialised countries which are largely multi-purpose but exposed to environmental control. Moving single purpose animals from human controlled environments into areas of environmental control causes lots of problems of mortality as animals have to some extend lost their ability to respond to environmental stresses (e.g. climate, quality of feed resources, fluctuating supply) and often die.
\end{abstract}

KEY WORDS: environment, climate, fecd resources, animal production

\section{INTRODUCTION}

I never cease to admire the way in which animals have managed to adapt to climate and quality of feed resources and indeed to seasonal fluctuation in feed availability. This ability to adapt by domesticated animals has been supported by the stock-keeper, as he was of course interested in their survival. In Europe many breeds of animals were selected and well adapted to climate and feed resources. In Scotland for instance we have the Highland cattle in the mountains with long hair and generally overwintered outside. In the lowlands, Aberdeen Angus was selected for better nutrition. The selection of animals until after the second world war was to a large extent for adaptation to climate and feed resources. However with a gradual progression to industrialisation in Western European countries and more so in the United States it became economically possible in many instances to 
have human control of the environment. Animals could be selected from high production of single products e.g. milk, beef and fibre. Breeding for more homogeneity with help of artificial insemination, embryo transfer and perhaps in the future cloning had economic interest in so far that profitability became more predictable. In the following I will refer to some important adaptations and discuss whether we need to change direction.

\section{ADAPTATION TO WARM ARID ZONE}

Clearly animals well adapted to arid zone have to accommodate at least two adverse effects. Firstly, a large fluctuation in nutrient supply and secondly very hot temperatures for at least part of the year. The adaptation to fluctuating nutrient supply is an ability to consume large amounts of feeds when the quality and quantity is good and also as a consequence and ability to preserve food in the form of body fat. It is usual at least for domestic ruminants that they tend to store fat in distinct regions of the body such as in humps of Zebu cattle and in tails and dewlaps of sheep.

The adaptation of allocating preserved food to distinct regions may well have implication for thermoregulation. In temperate zones the fat is normally evenly distributed subcutaneously. The camel seems to excel not only in ability to store fat when food is plentiful but also to have a water economy that enable it to wonder for nine days or more without water and biochemical adaptation to fasting with no elevation in blood $\beta$-hydroxy. (Wensvoort et al., 2001).

\section{ADAPTATION TO COLD REGIONS}

Off the best example here maybe the yak cattle in the Tibetan plateau and in Mongolia and indeed Scottish Highland cattle and many sheep breeds. They are generally distinguished by long hair and in the case of sheep wool. They have normally a voracious appetite in the summer season and become very fat but as mentioned earlier, unlike animals in arid zones the fat is generally evenly distributed subcutaneously.

\section{PHYSIOLOGICAL ADAPTATION TO HIGH CONSUMPTION OF ROUGHAGES}

It is a fact that with consumption of poor quality roughage there is a physical restriction to feed intake. These restrictions are both feed related and animal related. In some recent work we have attempted to classify the feed and animal charac- 
teristics influencing intake of roughages. When there is no nutrient deficiencies or antinutritional factors as:
A. Solubility
B. Insoluble but fermentable
C. Rate of degradation of $B$
D. Rate of reduction of long to small particles
E. Rate of outflow of small particles
F. Rumen volume

Clearly factors A B and C are feed related factors. Factors D and E are feed animal factors as at least the animals has to chew the feed. The propulsion of the rumen and characteristics of the feed influences the outflow rate. However rumen volume is clearly an animal characteristic and here we have probably inadvertently been selecting against this characteristic in Western Countries with environmental control. This is because in beef cattle high killing out percentage is taken as a positive breeding characteristic and clearly rumen volume is negatively correlated with killing out percentage or carcass weight as percent of liveweight. For dairy cows the quality of feed used has often been so high that rumen volume may not be too critical to achieve the highest intake. In fact Mould et al. (1983) found that the rumen content of native cattle in Bangladesh fed on rice straw was $33 \%$ of body weight while similar data on Friesian cattle was only $17 \%$ of body weight. As a result the cattle in Bangladesh consumed much more straw relative to body weight $3 \%$ as opposed to $1.5 \%$ of Friesian cattle. Clearly there has been a selection against rumen volume, which had consequences for voluntary intake of poor quality roughage.

\section{BIOCHEMICAL ADAPTATION}

Another adaptation which is less well documented refer to such aspects as glomerular filtration rate (GFR). This filtration via kidneys is effectively to clear the blood of waste products such as urea. On the whole the higher the metabolic potential the greater is generally the GFR. This has the advantage that waste products are disposed of quickly and by selecting for high productivity e.g. milk yield there has probably been a selection for high GFR as this is perhaps a condition for high turnover of metabolites. However a lower GFR allow for higher retention of waste products such as urea in the blood and this enable the animals to recycle more urea to the gut so that the animals are able to better utilise diets with a lower $\mathrm{N}$ content as urea recycling is directly proportional to plasma urea concentration (Whitelaw et al., 1987).

There is undoubtedly many other adaptations occurring such as tolerance or immunity to local diseases e.g. Trypanotolerant Ndama cattle in West Africa. Such adaptations of course would only occur if the local environment were allowed to 
exert its effect on selection or a kind of natural selection for survival. If on the other hand an animal is selected for a single purpose like milk production this is often associated with a sluggish insulin responses as discussed in detail by Cronje (2000). The problem then is that if the environment does not allow them to meet their genetic potential they do not reduce milk productions and develops ketosis and other discases associated with high production. The animals adapted to the environment are normally very varying probably because variability has survival value as the environment in one year is never completely like the next. The environment in two successive years may rank the animals different in terms of their growth rate, milk yield etc.

In Table 1 an attempt is made to contrast the livestock in market oriented single purpose with social value oriented and multipurpose; adapted from Ørskov and Viglizzo (1994).

TABLE 1

Distinction between marked oriented and single product animals and social value oriented and multipurpose animals

\begin{tabular}{lll}
\hline & \multicolumn{1}{c}{$\begin{array}{c}\text { Single purpose } \\
\text { Marked oriented }\end{array}$} & \multicolumn{1}{c}{$\begin{array}{c}\text { Multi purpose } \\
\text { Social value oriented }\end{array}$} \\
\hline Economic goal & Profit maxinization & Risk minimization \\
$\begin{array}{l}\text { Economic goal } \\
\text { Pconomic goal }\end{array}$ & $\begin{array}{l}\text { Cash generation } \\
\text { Productivity } \\
\text { Single purpose }\end{array}$ & $\begin{array}{l}\text { Family support } \\
\text { Stability and sustainability } \\
\text { Multi purpose }\end{array}$ \\
Control of environment & Human control & Environmental control \\
Breeding goal & Homogeniety & Biological diversity \\
Philosophical approach & Specialistic & Holistic \\
Scientific approach & Single discipline & System discipline \\
Statistical emphasis & Mean & Variance \\
Statistical emphasis & Main effects & Interactions \\
\hline
\end{tabular}

First of all contrasting the economic goals which clearly is profit maximisation, cash generation and productivity in the marked orientated sector while it is risk minimization, social value and stability in the social value orientated sector.

The most important is that often the environment is under human control. Thus beef animals are kept in feedlots at least during part of their lives with complete 
environment control so that weight gains, milk yield etc. is similar in dry and wet seasons and summers and winters. This has an effect on breeding goal which is homogeneity in the marked oriented sector as this increases the prediction of profitability. The homogeneity is achieved by use of tools such as artificial insemination and embryo transfer. For the social value sector diversity has survival value as the environment is not predictable but varies from year to year. Yet almost everywhere the animal research is focussed on homogeneity and simple products even if they are in the social value sector. The philosophical approach can be specialistic e.g. concentrated on one aspect of production while in the social value sector the philosophy has to be holistic, as animal production is part of a system interacting with plants and soils. Universities can be divided into single disciplines e.g. animal nutrition, animal production, animal breeding etc. While in the social value sector there should be system deciplines. Ironically the normal statistical emphasis on mean and main effect should in the social value sector be emphasis on the variance and interactions as this has survival value. See also under biological diversity.

\section{MOVEMENT OF LIVESTOCK BETWEEN THE TWO SECTORS}

Clearly animals from the social value sector will not generally be able to compete with animals on the single product for which they have been selected for many years to achieve. Generally, there is little direct transfer in that direction. However transfer of animals from marked oriented to social value oriented sector is pursued relentlessly by western livestock dealers pretending to solve problems and aid the farmer in the social value sector. Animal selected under environmental control and with high quality feed and single product are asked to produce and survive in an area where the environment is in control. There is plenty of examples of disasters and relatively few successes. The average lifespan of a Friesian cow exported to such areas is about 15 months. They have great problems and yet the businesses continuously relentlessly and uncritical as so called aid! Environmental control can be achieved by many means including importation of feed. It is however leaving a country very vulnerable. Intensive poultry in Indonesia was supported by cheap feed from America. When the currency was devalued by $80 \%$ two years ago $-80 \%$ of the poultry industry went bankrupt. The small farmers producing chicken from local resources survived. Various levels of crossbreeding with single purpose animals can be attempted. It is interesting to note that Cuba who based their breeding policy on the use of cheap feed from USSR are considering a reduction in the amount of Holstein blood in their dairy herds. An interesting trial from Vietnam is shown in Table 2, which show the effect of increasing the Holstein blood in F1 Holstein $x$ Red Sindhi cattle. The F2 is crossing F1 with Holstein to give $75 \%$ Holstein and F3 is crossing F2 with Holstein to give $87.5 \%$. 
TABLE 2

Records of F1 (50:50 Red Sindhi and Holstein), F2 (25:75 Red Sindhi and Holstein and F3 (12.5:87.5) Red Sindhi and Holstein

\begin{tabular}{lccc}
\hline & F1 & F2 & F3 \\
\hline No. recorded & 49 & 70 & 73 \\
Milk yield/lactation, kg & 3671 & 3858 & 3457 \\
Milk fat, \% & 3.8 & 3.7 & 3.7 \\
Milk protein, \% & 3.3 & 3.3 & 3.2 \\
Number insemination/pregnancy & 1.7 & 1.9 & 2.1 \\
Incidence of mastitis & 2.0 & 7.4 & 5.0 \\
Calving interval, days & 440 & 457 & 461 \\
Culling rate, first year & 5.0 & 6.3 & 7.9 \\
Breathing rate/min, mid-day & 41.8 & 45.7 & 49.7 \\
\hline
\end{tabular}

It can be seen that milk yield was not increased but the problems increased with increasing Holstein blood. Here the problem is climate depending as seen in breathing rate. The food intake is limited by the amount of heat that can be dissipated as there is no way of using air conditioning houses as in the Gulf States and Israel. It has to be recognised that at least $40 \%$ of metabolizable energy has to be dissipated as heat so that higher intakes led by higher production potential is impossible. This also means that the animals attempt to reach this potential by depleting body tissue, they stop cycling, they loose protein status and succumb easily to local diseases. In most instances feed quality is the limiting factors as it is too expensive to feed human food or concentrate to ruminants. The problem of feeds is often ignored. I believe one of the problems is our rather inappropriate feed evaluation systems in so far that they do not indicate how much the animals will consume. A roughage evaluation system based on feed potential which show how much of a given feed can be eaten relative to maintenance has been developed and may help to assist in having animals and production systems matched to feed potential and indeed to climate potential as well (Ørskov and Ryle, 1992; Ørskov, 1995).

Systems based on imported feeds are vulnerable to economic and political instability so is technology based on imported components. Kenya as a developing country was for a long time used as an example of a developing country where Al was successful. However a few years ago donors made aid depending on a change to multiparty systems. Al broke down, it was depending on liquid N, petrol, motorbikes etc. that were imported. A few years ago I was in Poland when Solidarność had to go underground. The farmers had been forced to use A1 from Holstein bulls, local bulls were prohibited. At that time Al broke down as liquid $\mathrm{N}$ was depending on import from the West. There are numerous examples. Pigs from the West are sent to Asia to improve quality e.g. less fat but quality is defined by Western perception as there is not problems of obesity there. 


\section{WHAT CAN WE DO TO IMPROVE?}

There is in my opinion no doubt that we in the future must pay more attention to animals being adapted to the environment rather than changing the environment to match the animals. This does not mean that we in the West need to change from the marked oriented to social value oriented sector. It means though that environmental constraints including climate and feed availability will be important. It will be led to some extent by consumers who will be prepared to pay more for products from animal husbandry situations that they approve of. It will be led also by cost of feed transport. It will be led by environmental control of waste disposal so as not to pollute watercourses and excess of $\mathrm{P}, \mathrm{K}$ and other minerals in soils close to concentrations of animals. It will be led by regulations involving less movement of animals. Recent outbreaks of foot and mouth disease in UK has provided ample evidence for that a disaster waiting to happen. Movement of animals from one end of the country to another to be slaughtered in a few specialised slaughterhouses or sold in very large marked and kept in large units may have come in for a shock. Animal breeding centres could already begin to make a move so that they can help to lead an inevitable development. At present they all seem bent on selection for homogeneity and high production of single products under environmental control.

\section{REFERENCES}

Cronje P.J., 2000. Nutrient gene interactions. In: P.J. Cronje (Editor). Ruminant Physiology Digestion, Metabolism, Grants and Reproduction. CABI Publishing (UK), pp. 409-422

Nguyen Q.D., 1998. Breeding performance of crossbred Holstein and Red Sindhi in South Vietnam. PhD Thesis. University of Agriculture, Hanoi

Ørskov E.R., 1995. Futterpotential der Tropen und Subtropen in Nutztierernährung PotentialeVerantwortung-Perspektiven. H. Abel, G. Flachowsky, H. Jeroch, S. Molnar (Editors). Gustav Fischer Verlag, Jena, Stuttgart, pp. 62-75

Ørskov E.R., Ryle M., 1990. Energy Nutrition in Ruminants. Elsevier Applied Science, London, New York

Ørskov E.R., Viglizzo E.F., 1994. The role of animals in spreading farmers' risks: A new paradigm for animal science. Outlook Agr. 23 (2), 81-89

Ørskov E.R., Tait C.A.G., Reid G.W., 1981. Utilization of ammonia treated or urea treated barley straw as the only feed for dairy heifers. Anim. Prod. 32, 388 (Abstr. 105)

Wensvoort J., Kyle D.J., Ørskov E.R., Bourke D.A., 2001. Biochemical adaptions of camelids during periods where feed is witheld. Rangifer (in press)

Whitelaw F.G., Milne J.S., Ørskov E.R., 1987. Urea metabolism in sheep nourished by intragastric infusion. Proceedings of 5th International Symposium on Protein Metabolism and Nutrition. Rostock (GDR), p. 82 


\section{STRESZCZENIE}

\section{Potencjal produkcyjny zwierząt a warunki klimatyczne i baza paszowa}

Opisano zdolność zwierząt określonego środowiska do adaptacji klimatycznej i zmieniającej się jakości dostępnych pasz. Przyjęcie intensywnego systemu produkcji zwierzęcej przez uprzemysłowione kraje, opartego zazwyczaj na selekcji w kierunku uzyskania najlepszych wyników pod względem określonych cech produkcyjnych, np. mleka, mięsa, welny itp., w kontrolowanych przez człowieka warunkach środowiskowych jest zagadnieniem dyskusyjnym. Kontrastuje to z warunkami w jakich utrzymywane są zwicrzęta w mnicj uprzemyslowionych krajach, w których preferowana jest wielokierunkowa produkcja zwierzęca w innych często warunkach środowiskowych. Przeniesienie zwierząt o określonym, jednym kierunku produkcji z warunków środowiskowych kontrolowanych przez człowieka do obszarów, gdzie środowisko ksztaltuje produkcję, stwarza liczne problemy zdrowotne spowodowane tym, że zwierzęta traca w znacznym stopniu zdolność dostosowania się do stresów wywołanych zmianą środowiska (np. klimat, jakość i dostępność pasz), co często prowadzi do upadków zwierząt. 